\title{
Naglasak pridjeva u govornoj praksi ${ }^{1}$
}

\author{
Izvorni znanstveni rad \\ Original scientific paper
}

UDK 811.163.42'367.2.623

\begin{abstract}
$U$ radu se analiziraju odstupanja od kodificirane naglasne norme u govornoj praksi na korpusu čestouporabnih pridjeva. Odstupanja su zabilježena i na leksičkoj i na paradigmatskoj, pa onda i na tipološkoj razini. Uočavaju se tendencije dokidanja međuslogovnih naglasnih preinaka, tonske opreke kratkih slogova, tendencija širenja distribucijskoga polja silaznih naglasaka, jaka tendencija pomicanja naglaska prema početku riječi te gubljenja zanaglasnih dužina. Neke od njih nalazimo već i u suvremenim priručnicima.
\end{abstract}

Ključne riječi: pridjevi, naglasak, naglasna norma, kodeks, uzus, govorna praksa

\section{Uvod}

$\mathrm{N}$ aglasna norma hrvatskoga standarda danas je uvelike učvršćena, no razilaženja uzusa i kodeksa još uvijek nalazimo. Normativna previranja (između istočnonovoštokavskih i zapadnonovoštokavskih obilježja) većega dijela 20. stoljeća danas su prevladana i današnja se kodificirana norma približava uzusu, jezičnoj praksi. Budući da suvremeni priručnici ne pristupaju jednako proširenim naglasnim likovima, među njima nema u svemu suglasja (posebice kad je riječ o leksičkome ili tipološkome naglasku). Takvo stanje odaje da naglasna norma nije potpuno stabilizirana.

Vrludanja između norme i prakse prikazat ćemo u ovome radu na primjeru naglašivanja pridjeva. ${ }^{2}$ Ići ćemo tragom akcentoloških istraživanja (usp. Martinović 2006) koja su pokazala da se odmaci od kodificirane naglasne norme hrvatskoga standardnog jezika tiču inventara i raspodjele naglasaka, redom: a) silazni se ton javlja i na nepočetnim slogovima riječi te je dijelom i leksičkoga i paradigmatskoga naglašivanja; b) čest je izostanak zanaglasnih dužina; c) slogovi su bez tonske opreke u određenim gradskim sredinama (i govor je na tragu dinamičkoga naglaska); d) uzlazni se naglasak sve više pomiče ulijevo; e) određene su paradigmatske naglasne preinake u uzmaku. Promjene tona u neodređenih oblika (spör - spòra - spòro); međuslogovne naglasne preinake (màlen - malèna - malèno) te zanaglasne dužine (văljān - văljāna - văljāno) u pridjeva pojave su koje u govoru nestaju. Jednake su tendencije zabilježene i u drugih vrsta riječi; primjerice u imenica se sve više dokidaju paradigmatske preinake (festivāl - festivála $\rightarrow$ fèstivāl - fëstivāla), gube se u govoru zanaglasne dužine, što je i u priručnicima zabilježeno posebice nakon dugouzlaznoga naglaska (plitkoúmnost, rástem) i sl. Naglasne preinake sve se više doživljavaju stilski obilježenima (u govòru : u gövoru), pa je tako i u pridjeva (väljān - valjána - valjáno).

Rad je dijelom završnoga rada studentice Jelene Pudić, obranjenoga u rujnu 2012.

Pridjevi (adjektivi) označuju stvarna ili zamišljena statična obilježja predmeta mišljenja izrečenih imenicama i drugim vrstama riječi koje označuju samostalne pojave. (S. Babić et al. 2007: 422) 
Razlikovanje neodređenoga i određenoga oblika pridjeva naglaskom također je u govoru zanemareno, posebice kad je riječ o međuslogovnim preinakama (dugàčak - dugàčka dugàčko : dùgačkī-dùgačkā - dùgačkō), i to u korist naglaska određenih oblika pridjeva (dùgačak-dùgačka-dùgačko).

Sva navedena odstupanja, nakon komparativne analize suvremenih priručnika (gramatika, rječnika i savjetnika), analizirat ćemo u praksi. Anketiranjem tzv. profesionalnih govornika želimo dokučiti koja su i kolika su razilaženja uzusa i kodeksa na zadanome korpusu. Cilj je utvrditi je li naglasna opreka još uvijek razlikovno sredstvo pridjevnih oblika jer se u literaturi navodi (Pranjković 1998) da je razlika određenih i neodređenih očuvana na prozodijskoj razini (iako formalne, u tipu sklonidbe, polako nestaju). Naglasak tako čuva način izražavanja kategorije određenosti u pridjeva, i ondje gdje primarni (gramatikalizirani) način nestaje pa ostaju sekundarni načini izražavanja određenosti ili neodređenosti (padežima, redom riječi, rečeničnim naglaskom, leksičkim sredstvima i sl.). Osim toga, dokučit ćemo koliko su snažne suvremene naglasne tendencije (kao što je silazni ton nepočetnoga sloga, pomicanje naglaska ulijevo, gubljenje zanaglasnih dužina) i u pridjeva.

\section{O naglasku pridjeva}

Određenost i neodređenost jedna je od četiriju gramatičkih kategorija pridjeva koja se navodi u svim suvremenim gramatikama hrvatskoga jezika (pored roda, broja i padeža). No valja imati na umu da se čuje i drugačijih mišljenja: "nije riječ o osobitosti svojstva (koje se izražava pridjevom), nego o osobitosti predmeta (koji označuje imenica)". (Pranjković 1998) Zamijećeno je da se formalne razlike između "gramatikaliziranih načina izražavanja" te kategorije sve više gube (nominativ muškoga roda tomu odolijeva). Sklonidba neodređenih pridjeva u svakodnevnome je govoru i pismu u uzmaku, naime formalno se izjednačuje sa sklonidbom određenih pridjeva (iako ne uvijek i naglaskom cŕnōg i crnōg).

Kategorija određenosti u pridjeva za akcentologe je zanimljiva iz nekoliko kutova: leksički se promatra naglasak $\mathrm{N}$ jd., paradigmatski metatonija naglaska i zanaglasne dužine u fleksiji, a tipološki modelska promjena prozodijskih obilježja (mjesta, tona, trajanja).

U naglasnome tipologiziranju uzimamo u obzir samo naglasna obilježja pa u skladu $s$ tim sve vrste riječi svrstavamo u dva osnovna tipa: promjenljivi i nepromjenljivi. ${ }^{3} \mathrm{U}$ nepromjenljivome tipu pridjeva naglasak je stalan u svim rodovima te u obje sklonidbe (imenična i pridjevno-zamjenična), za razliku od promjenljivoga tipa.

U neodređenome obliku pridjeva u hrvatskome standardnom jeziku naglasak se mijenja po rodovima (od muškoga prema ženskome i srednjemu: žût - žúta - žúto; ili od muškoga i srednjega prema ženskome rodu: sjâjan - sjâjno - sjájna) te u paradigmi muškoga roda (u jednini primjerice N žût, G žúta, D žútu, A žût/žúta, V -, L žútu, I žútīm). Zanaglasne dužine javljaju se u GDL jd. ženskoga roda, u I jd. te GDLI mn. svih rodova.

Pridjevi koji mijenjaju naglasak u paradigmi mogu promijeniti ili ton (žût - žúta - žúto; zdràv - zdràva - zdràvo; žédan - žêdnî), ili ton i trajanje (bôs - bòsa-bòso/bòso), ili mjesto naglaska (màlen - malèna - malèno).

U određenome obliku pridjeva naglasak se ne mijenja ni po rodovima (žûtī-žûtā-žûtō) ni u sklonidbi (primjer jedninske paradigme: G žûtōg(a), D žûtōm(u), A žûti/žûtōg(a), V žûti, L žûtōm(e), I žûtīm). Zanaglasne dužine gramatičkih morfema dolaze u svim rodovima u cijeloj paradigmi.

Puno oprimjerenje takva promišljanja nalazimo u monografiji Naglasak u hrvatskome književnom jeziku S. Vukušića, I. Zoričića i M. Grasselli-Vukušić. Poglavlje o pridjevima sastavio je I. Zoričić. 
Predvidljiv (automatiziran) naglasak imaju i komparativi i superlativi. Komparativi imaju kratki naglasak: silazni je u dvosložnih (žüćî), a u trosložnih i višesložnih uzlazni na trećem slogu od kraja (stàrijī). Superlativi su dvonaglasni u većini priručnika (nose stalni naglasak prefiksa nâj, točnije sporedni naglasak, te naglasak komparativa kao druge osnove), no jedan je naglasak sustavniji u hrvatskome standardnom jeziku, jedna govorna riječ jedan naglasak (prema pravilu u Silić-Pranjkovićevoj gramatici o trosložnim i višesložnim superlativima: nâjžućí, najstàrijiī), osim ako nije posrijedi kakvo isticanje. U višesložnica se ostvaruje i automatski sporedni naglasak (jeka), no riječ je samo o isticanju siline prvoga dijela. Ni komparativi ni superlativi nemaju naglasnih promjena u sklonidbi, imaju samo određeni oblik pa se sklanjaju kao pridjevi određenoga oblika (s osnovom na nepčanik).

Stalni naglasak imaju i neke pridjevske tvorenice, naime pridjevi na -ov, -ev, -in, -ljiv zadržavaju naglasak genitiva jednine imenice od koje su tvoreni (strîc, stríca > stríčev), a dvosložni na -ov, -ev imaju kratkouzlazni naglasak (dùbov). Takav je naglasak i u pridjeva sa sufiksom -at (ùhat) i u pridjeva sa sufiksom -āći (kùpāćî). Kratkouzlazni imaju i opisni pridjevi na -iv, -jiv, -ljiv, -ovit, -evit, i to na drugome slogu od kraja (bregòvit, pàžljiv). Konačno, kratkouzlazni naglasak pred sufiksom imaju pridjevi koji se tvore od stranih imenica na -ist (optimističkî). (Vukušić et al. 2007: 113).

U složenica je ili kratkouzlazni naglasak na spojniku (bosònog), ili ostaje naglasak drugoga dijela složenice (brakorázvodnī, izvanstränačkī), ili je naglasak prve osnove (mìrotvōran). Gdjegdje se donose i dva naglaska (ültraljübičast), no u izgovoru je zapravo riječ o naglasnoj jeki. U suvremenim se priručnicima navodi da je izgovor osnovno mjerilo razgraničenja jednonaglasnih od dvonaglasnih složenica, no tada valja uzeti u obzir i pisanje dijelova složenice odvojeno (pri čemu se pravopisna i pravogovorna norma isprepleću). Suvremeni priručnici tako donose i svijétlomödar, i svijétlomodar, i svjetlòmodar, no budući da različita pravila pisanja prate različite govorne ostvaraje, kao što je to u primjera $\mathrm{s}$ kraćenjem jata ispred naglaska, valja uzeti u obzir da se i složenice koje se govore sa stankom među dijelovima pišu odvojeno ili sa spojnicom. U složenica su česta naglasna kolebanja, javljaju se dvostrukosti pa i trostrukosti, što i nije neobično na leksičkoj razini. Detaljnija istraživanja funkcionalnostilske raslojenosti takvo stanje može uvelike rasvijetliti (primjerice u znanstvenome stilu bilo bi preporučljivije bosònog, a u razgovornome je češće bòsonog).

Zanaglasne dužine u govornoj praksi (koja ih i inače ostvaruje) stabilnije su u pridjevnoj osnovi od onih gramatičkih. Posebice se čuva dug slog osnovne riječi (gospòdār gospòdārskī) te onaj nastao položajnim duljenjem, pred skupinom sa sonantom (siròtinjasiròtīnjskì), što je uočljivo i ispred sufikasa (lìterārnī, fïzikālnī, kömercijālnī, vìzuālnī, düšēvnī, fäbulatīvnī...). Stabilne su i dužine pred -(a)n (dïjetālan, pärlamentāran, nēstāšan, ljübāzan, rëligiōzan, tëkstuālan...).

\section{Pridjevi u govornoj praksi}

\section{Upitnik}

Naglasak pridjeva ispitivali smo na uzorku od petnaest rečenica s petnaest pridjeva u kojih očekujemo odstupanja. Prvu skupinu čini pet rečenica s pridjevima u kojih se opreka određenost/neodređenost utvrđuje naglaskom, tj. promjenom tona ili mjesta, jer želimo provjerili razlikuju li ispitanici naglaskom oblike pridjeva (ili je pomak k određenosti). U sljedećoj su skupini pridjevi u kojih se nerijetko čuje silazni ton na nepočetnome slogu pa smo istražili koliko ispitanika to i ostvaruje (biokêmījskī, maloâzījskī, televîzījskī, iznadprösječna, što se onda širi i na ostali dio korpusa kao što je u primjeru stolnotèniskī). Posljednjom smo skupinom pridjeva ispitali suvremenu tendenciju pomicanja naglaska prema početku 
riječi (pìrenējskī, jëdnofāznō, mëdicīnskī, vǐšednēvnī, plìtkoūman). Naposljetku smo ispitali ostvarivanje zanaglasnih dužina u pridjeva. Upitnik (ovdje i naglašen prema suvremenoj priručničkoj literaturi ${ }^{4}$ ) izgledao je ovako:

1. skupina: razlikovanje određenih i neodređenih pridjeva

- Kuća je tvŕda i stamena, a pod njom bijaše tvr̂́ā ilovača.

- $\quad$ Proljeće je bilo dugo i mòkro pa je zavilo u sumrak to malo mökrō seoce.

- Prozori su bili sasvim mráčni pa su dodatno pojačali mrâčnī ugođaj.

- Trči kroz snijeg gola i bòsa pa joj bösā stopala pocrvenješe.

- Naše je društvo šarèno kao šàrenō uskrsno jaje.

2. skupina: silazni naglasci izvan početnoga sloga

- U subotu se organizira stolnotèniskī/stolnoténiskī turnir u našem gradu.

- Ona je iznadpròsječna/iznadprösječna.

- Uzorke nosimo u biokèmijskī/biokèmījskī/biokémijskī/biokémījskī laboratorij.

- Na Korčulu su dolazili maloàzijskī/maloàzījskī/malâzījskī trgovci.

- Televìzijskī/televízījskī program jako je zanimljiv.

3. skupina: tendencija pomicanja naglaska prema početku riječi

- Potomak je arapske doge i pirènejskī/pirènējskī planinski pas.

- U stanu imamo jednòfāznō/jèdnofāznō brojilo struje.

- Sanja je upisala medicīnskī/mèdicīnskī fakultet.

- Idemo na višèdnēvnī/vīšednēvnī izlet u Gorski kotar.

- Zvonimir nije plitkòūman/plìtkoūman, samo nepažljiv.

4. gubljenje zanaglasnih dužina (u gore navedenim primjerima)

\section{Ispitanici i statistički postupak}

Istraživanje smo proveli među 45 studenata i studentica preddiplomskoga i diplomskoga studija kroatistike Sveučilišta Jurja Dobrile u Puli (prosjek godina: 21) te 22 gimnazijskih profesora i profesorica u Puli (prosjek godina: 45 ), ukupno ispitanika: $\mathrm{N}=67 .{ }^{5}$ Često se navodi da su mediji, javni istupi i pedagoška praksa prilike gdje se ostvaruje općeobvezatni, formalni, neutralni, referencijalni tip standardnog jezika. ${ }^{6}$ Tomu svjedoči i definicija standarda u kojoj stoji da se rabi u edukacijskome procesu u javnim institucijama i u medijima, tj. namijenjen je "upotrebi u državnoj upravi, školstvu, sredstvima masovnih komunikacija i, djelomično, u literarnoj produkciji." (Škiljan, 1988: 49) Akcentološka se istraživanja standardnoga jezika tako ograničuju na tzv. profesionalne govornike (primjerice profesore, različitih startnih govora) jer se drži da bi upravo oni bili jedni od nositelja standardnoga izgovora, po načelu: "govori, kako govori jezično obrazovana javnost". (Esih (1931-1932) 1999: 47) Osim profesora profesionalnim se govornicima smatraju i glumci i spikeri (gdjegdje se uzima u obzir i govorna praksa novinara i ostalih govornika kada se ocjenjuje proširenost kojega lika). U ovome su radu srednjoškolski profesori i studenti kroatistike različitih startnih idioma modelski govornici. Zadovoljili smo neke od temeljnih zahtjeva, koje je definirao, između ostalih, I. Zoričić (1990: 50): informant je intelektualac, javno mu je govorenje sastavnim dijelom zanimanja i dijelom je skupine koja pokriva cijelo područje hrvatskoga standardnog jezika. Startni mu jezik nije samo novoštokavski idiom (u našemu istraživanju trećina je i studenata i profesora štokavaca), na čemu su inzistirala starija istraživanja, upravo s razloga

Dvostrukosti i višestrukosti koje se javljaju u priručnicima pojasnit ćemo u poglavlju o rezultatima istraživanja.

Zahvaljujemo gimnazijskim profesorima i profesoricama u Puli što su strpljivo i savjesno obavili zadatak te nas u ugodnome ozračju ugostili u svojim prostorijama. Zahvaljujemo i studentima i studenticama kroatistike u Puli što su svoje slobodno vrijeme odvojili za nas.

6 Primjerice S. Vukušić (1974.), I. Zoričić (1990.), H. Delaš (2006.) itd. 
jer se želi doseći koliko je naglasni sustav standardnoga jezika moguće naučiti kad su razlike startnoga idioma i standardnoga veće. Profesionalni govornik (modelski govornik, language guardians) termin je kojemu valja dati prednost pred "bolja jezična praksa", naime potonji unosi kvalitativnu oznaku kojoj nasuprot stoji "gora jezična praksa". Spoznaje o funkcionalnostilskome raslojavanju jezične stvarnosti idu u prilog tezi da nema boljega ili lošijega izgovora, postoji naime samo neutralno i stilski obilježeno. ${ }^{7}$

Ispitanici su rečenice čitali bez prethodne pripreme i nasamo, a prema snimkama smo govorenih ostvaraja potom transkribirali snimljeni materijal i slušnom percepcijom naglasili pridjeve. Prije deskriptivne statističke obrade rezultata upitnik i transkripciju verificirala je suautorica ovoga rada (B. M.). Dobivene smo rezultate prikazali grafovima.

\section{Rezultati istraživanja}

Graf 1. Razlikovanje određenoga i neodređenoga pridjeva naglaskom

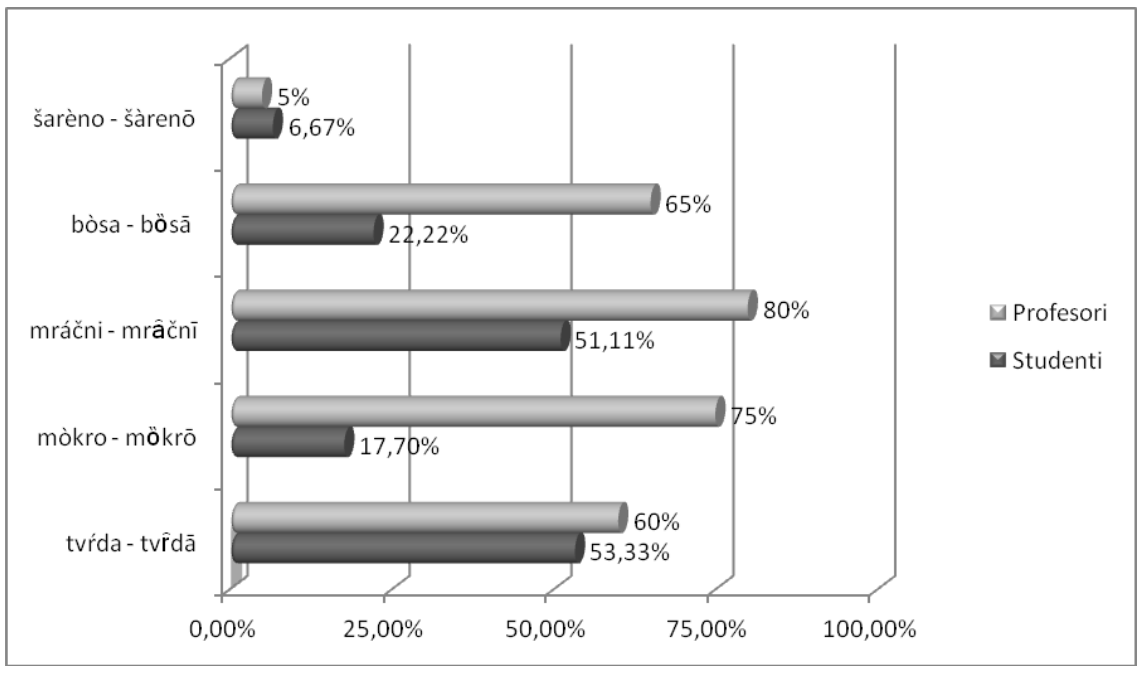

Mlađi i stariji govornici, zamijetili smo, ne razlikuju jednako određene i neodređene pridjeve naglaskom, nešto bolje to čine profesori (posebice stariji, u čemu vidimo posljedicu obrazovnoga sustava, naime u nastavnoj se praksi sve manje obrađuje prozodija hrvatskoga jezika, što su posvjedočili i anketirani profesori, a svjedoči i nastavni program u kojemu nema prostora za paradigmatske smjene naglasaka) i oni kojima je štokavština startni idiom. Međuslogovne preinake manje se čuvaju od onih metatonijskih, istoslogovnih. $U$ govoru tako dio riječi prelazi iz promjenljivoga u nepromjenljivi tip (šàren - šarèna - šarèno $\rightarrow$ šàren - šàrena - šàreno). Gdjegdje i priručnici donose takva uporabna stremljenja (primjerice Hrvatski jezični savjetnik). Također je zamjetljivo da je metatonija dugih naglasaka stabilnija od one kratkih što može ići u prilog tezi da u govoru prvo nestaje tonska opreka kratkih naglasaka, posebice u gradskim sredinama, primjerice u sjeverozapadnoj Hrvatskoj, u Istri i Rijeci. Moguće pomake od jednonaglasnoga prema tzv. dinamičkome naglašivanju uočavamo u mlađih ispitanika, i u primjera mračni, tvrda. U ostalih se nazire dominacija naglasaka

Na istome je tragu i K. Mićanović (2006: 72) opisujući poznato Trudgillovo (Sociolinguistics, 1995.) stajalište o standardnome varijetetu prema ostalim varijetetima, naime uporaba termina "viši stil" i "biraniji izričaj" negativno kvalificira izražavanje koje nije standardno. 
određenih oblika pridjeva, posebice u kratkih naglašenih slogova. Počesto zanaglasna dužina ostaje razlikovni element kategorije određenosti u pridjeva kad se u rečenici nađu i određeni i neodređeni pridjev, u suprotnom dužine nestaju.

Graf 2. Silazni naglasak na nepočetnome slogu

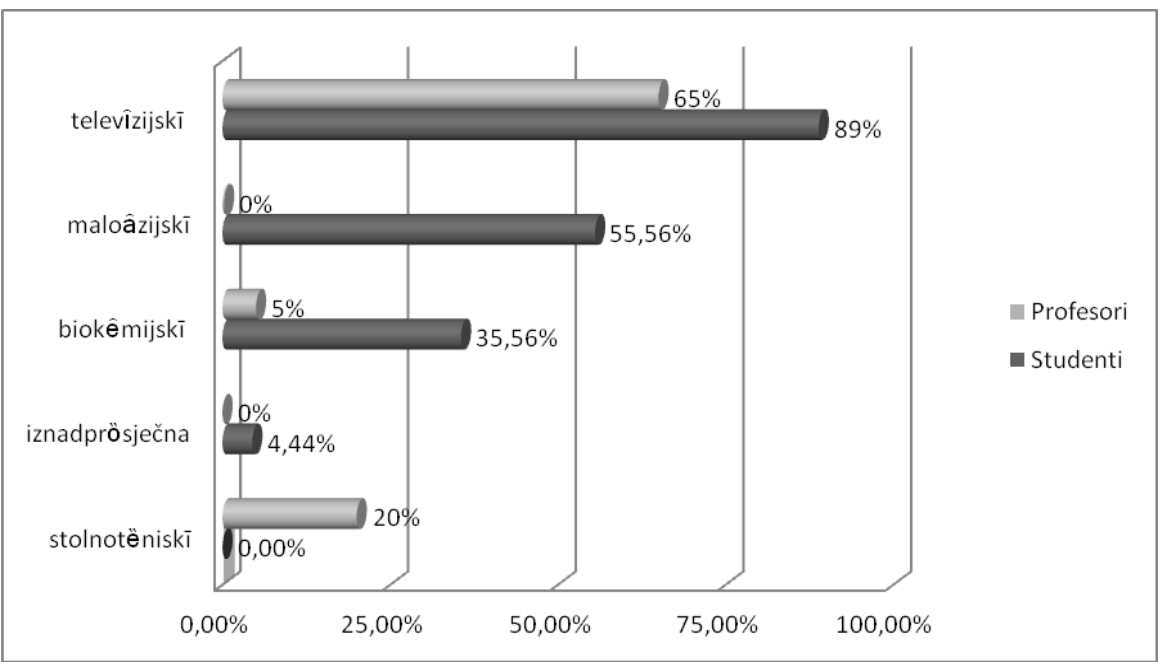

Silazni se naglasci na nepočetnim slogovima javljaju i u domaćim riječima i u posuđenicama (G mn. rečènīcā, G mn. podâtākā, poljoprìvreda; Austrâlija, radijâtor i sl.). I u suvremenim gramatikama i rječnicima nalazimo likove sa silaznim naglascima nepočetnoga sloga što svjedoči o tome da u jeziku kao standardu može biti i onoga što jezik kao sustav ne podupire. U monografiji Naglasak u hrvatskome književnom jeziku silazni je ton nepočetnoga sloga u složenih pridjeva donesen u slučajevima "kad takvo naglašavanje preteže nad ostalim mogućnostima”. (Vukušić et al., 2007: 134) Ostali priručnici još uvijek ne donose sustavno proširene naglasne likove (skloniji su metatoniji, kao što je primjerice u Hrvatskome jezičnome savjetniku zabilježeno vjëkōvan, ali srednjovjèkōvan), premda su se ustalile i izbistrile tvorenice u kojima drugi dio nosi silazni ton i izvan nje (protupöžārnī, poljoprïvrednī, srednjovjēkōvan, radiodrâmskī, zemljovlâsničkī...).

Iz grafičkoga prikaza rezultata može se vidjeti da ispitanici katkad čuvaju naglasak osnove (televîzija, Âzija, kêmija, prösječna/pròsječna), ali i to da silazni naglasak, manjim dijelom (u govornika neštokavaca), ostvaruju analogijom i u drugih višesložnica koje nisu u standardu motivirane osnovom sa silaznim tonom (tènis/ténis). Uočili smo i da su stariji govornici većma izbjegavali silazni ton nepočetnoga sloga (posebice u primjeru maloàzījskî), a gdjegdje smo zamijetili i dva tipa standardnoga naglašivanja, mediteranski tip standardnoga jezika (biokèmījskī, stolnotèniskī, televìijskī) i kontinentalni tip standardnoga jezika (biokémījskī, stolnoténiskī, televízijjskì). Prvome je tipu sklon priručnik Naglasak u hrvatskome književnom jeziku, a drugome Hrvatski enciklopedijski rječnik.

Ispitanici su naglašavali katkad i dvama naglascima (tj. uočili smo i pravi sporedni naglasak), gdjegdje želeći istaknuti primjer koji su čitali, što se uočilo i iz stanki i intonacije rečenice, čime je takav lik ekpresivno obilježen (ìznadprösječna, stôlnotèniskī, bìokêmijskī), a gdjegdje je bila riječ o automatskome sporednome (sekundarnome) naglasku u višesložnica (samo s oznakom siline u prvome dijelu 'iznadprösječna, 'stolnotèniskī, 'biokêmijskì). 
Graf 3. Tendencija pomicanja naglaska prema početku riječi

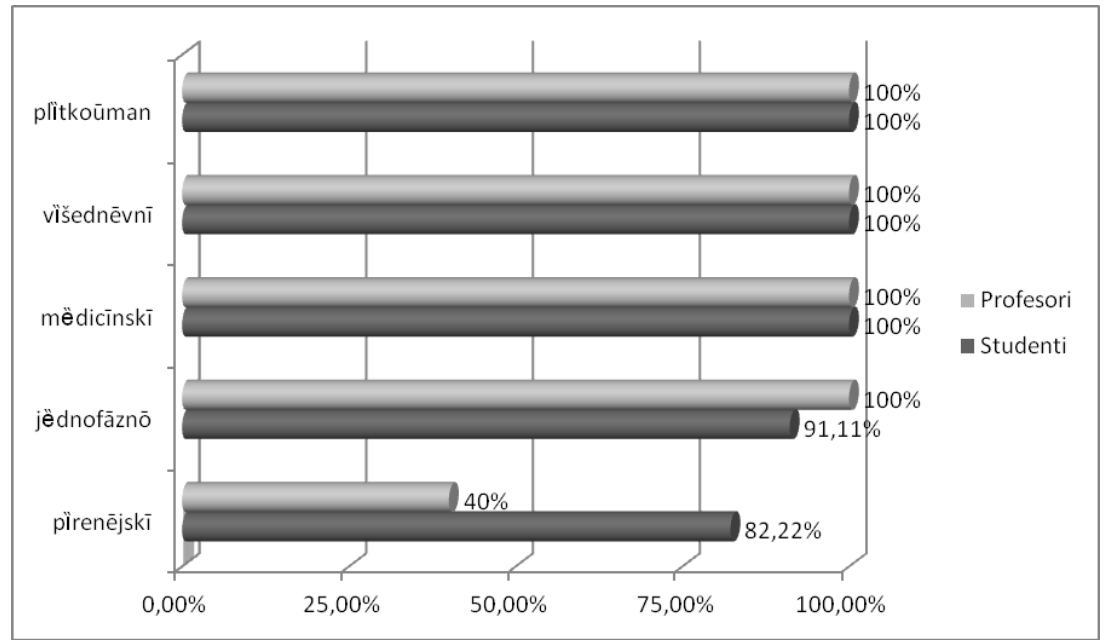

Rezultati analize našega istraživanja pokazali su da svi ispitanici pomiču naglasak prema dočetku u pridjeva plitkòūman, višèdnēvnī i medicīnskī, nešto manje u pridjeva jednòfāznō i pirènējskī. Valja istaknuti da je čelni naglasak zabilježen i u suvremenim priručnicima, primjerice Hrvatski enciklopedijski rječnik donosi plïtkoūman, mëdicīnskī, jëdnofāzan... Norma je "popustljiva" prema pomicanju naglaska ulijevo u većine (vrsta) riječi (dühōvnōst, pröstodūšnōst, òdasvud, ùnatoč...), izuzimlju se glagoli u kojih su takvi ostvaraji i dalje hiperkorektni (prëpīsati, nè nāpišēèm). Suvremeni su priručnici u ovome dijelu na tragu proširenih likova, pri čemu postaju i prihvatljivi i prihvaćeni. Nepomaknuti naglasak (plitkòūman, višèdnēvnī, medicīnskī, jednòfāznō, pirènējskī) ipak se i dalje doživljava učenim i ispitanici bi ga preporučili primjerice u znanstvenome stilu (što su u intervjuu i sami istaknuli). ${ }^{8}$

\section{Ostvarivanje zanaglasne dužine}

Osluškivali smo i u kojoj mjeri ispitanici ostvaruju zanaglasne dužine u pridjevima iz upitnika. Zanaglasne dužine u manjoj mjeri izostavljaju štokavski govornici te profesori hrvatskoga jezika. Također se najmanje izostavljaju u određenim pridjevima, posebice kad je dužina razlikovni element (od 65 do $90 \%$ ispitanika, posebice profesora, izgovorilo je u pridjeva tvr̂āa, mökrō, mrâčnī, bōsā, šàrenō). Uočili smo i da su stabilnije dužine u pridjevnoj osnovi od onih u nastavku (jednofāzno, plitkoūman, višednēvni, medicīnski), čak oko 90\% ispitanika izgovorilo je dužine koje su motivirane "svježim i živim" fonetskim preoblikama (fâzno - jednofāzno; ûman - plitkoūman), nešto manje su izgovarali dužine koje su pred skupom sa sonantom (češće iza kratkoga sloga pirenējskī, nego iza dugoga sloga biokemījskī, televizījskī, maloazījskî). U posljednjim primjerima vrlo se rijetko ostvaruju obje dužine, prvo otpada ona etimološka, na gramatičkome nastavku.

Istraživanje imenica na -ōst (Martinović 2009) također je pokazalo da gramatike daju prednost liku s naglaskom na spojniku (ćudòrednōst), rječnički priručnici nude i lik s naglaskom pred sufiksom ili čelni (u kontinentalnome dijelu češće ćudorédnōst, u mediteranskome ćüdorednōst), a u formalnim situacijama ispitanici su odabirali češće lik s naglaskom na spojniku. 


\section{ZAKLJUČAK}

Na tragu suvremenih akcentoloških istraživanja i ovdje smo pokazali da su odmaci od kodificirane naglasne norme hrvatskoga standardnog jezika, koji se tiču inventara i raspodjele naglasaka, odreda zabilježeni i u pridjeva. U uporabi je prošireno, a dijelom kodeksom i poduprto sljedeće: silazni se ton javlja i na nepočetnim slogovima riječi (u pridjevnih složenica/ tvorenica) i uzlazni se naglasci sve više pomiču ulijevo (što kodeks najviše podupire). Još se uvijek (opravdano) ne propisuje i prošireno dokidanje tonske opreke kratkih slogova (jer to bi zatim zahvatilo i duge slogove) te međuslogovnih preinaka naglasaka u neodređenih pridjeva (što utječe i na tipološka razvrstavanja, prelazak riječi iz promjenljivoga u nepromjenljivi tip). Budući da je naglasak još uvijek razlikovni element u kategoriji određenosti/neodređenosti (i onda kada se formalni, gramatikalizirani, sve više gubi), kodeks je čvrst, a još je čvršći kad su posrijedi etimološke zanaglasne dužine, jer su one razlikovni element i kad naglasak nije (i u katogoriji određenosti/neodređenosti, i kada se primjerice razgraničuju pridjevi od priloga). Funkcionalnostilsko raslojavanje jezične stvarnosti i ovdje će pripomoći u opisivanju proširenih dvostrukosti i višestrukosti. Razgovorni su likovi (prihvatljivi i prihvaćeni) već našli svoje mjesto u suvremenim priručnicima, potrebno ih je samo sustavno i dosljedno prikazati.

\section{POPIS LITERATURE}

\section{ANIĆ 1998}

Vladimir Anić, Rječnik hrvatskoga jezika, Novi Liber, Zagreb 1998.

\section{BABIĆ 1968}

Stjepan Babić, "O Daničićevu naglasnom sustavu kao sustavu", Jezik, XV/5, Zagreb 1968., 150 $-157$.

\section{BABIĆ 1986}

Stjepan Babić, Tvorba riječi u hrvatskom književnom jeziku, JAZU, Zagreb 1986.

\section{BABIĆ ET AL. 2007}

Stjepan Babić et al., Glasovi i oblici hrvatskoga književnog jezika, Nakladni zavod Globus, Zagreb 2007.

\section{BARIĆ ET AL. 1995}

Eugenija Barić et al., Hrvatska gramatika, Školska knjiga, Zagreb 1995.

\section{BARIĆ ET AL. 1999}

Eugenija Barić et al., Hrvatski jezični savjetnik, Institut za hrvatski jezik i jezikoslovlje, ŠN, Pergamena, Zagreb 1999.

\section{BROZOVIĆ 1958}

Dalibor Brozović, "Normiranje književnih naglasaka", Jezik, VI/3, Zagreb 1958., 65-73.

\section{DELAŠ 2002}

Helena Delaš, Silazni naglasci na nepočetnim slogovima, magistarski rad. Filozofski fakultet, Sveučilište u Zagrebu, Zagreb, 2002.

\section{DELAŠ 2006}

Helena Delaš, "Proučavanje hrvatske prozodije u 20. stoljeću", Hrvatski jezik u XX. stoljeću Zbornik radova, Matica hrvatska, Zagreb 2006., 71-89.

\section{ESIH (1931-1932) 1999}

Ivan Esih, "Kultura književnog jezika (Deset jezičnih zapovijedi)", Norme i normiranje hrvatskoga standardnoga jezika, pr. M. Samardžija, Matica hrvatska, Zagreb 1999., 42-48. (izvornik: Nastavni vjesnik, 1931.-1932., XL: 191-196)

\section{JOJIĆ - MATASOVIĆ 2002}

Ljiljana Jojić, Ranko Matasović (ur.), Hrvatski enciklopedijski rječnik, Novi Liber, Zagreb 2002. 


\section{JONKE 1965}

Ljudevit Jonke, "Distributivni singular i plural", u: Književni jezik u teoriji i praksi, Zagreb 1965., str. 373-376.

\section{LUPIĆ 2001}

Ivan Lupić, "Preskriptivna akcentologija i hrvatski standardni jezik", Kolo, XI/1, Naklada Matice hrvatske, Zagreb 2001., 85-135.

\section{MARKOVIĆ 2010}

Ivan Marković, Uvod u pridjev, Disput, Zagreb 2010.

\section{MARTINOVIĆ 2006}

Blaženka Martinović, „Odmaci od preskriptivne naglasne norme $u$ hrvatskome standardnom jeziku", Riječki filološki dani - Zbornik radova VI, 2006., 247-259.

\section{MARTINOVIĆ 2009}

Blaženka Martinović, "Kolebanja leksičkoga naglaska imenica i-vrste"; Croatica et Slavica ladertina, V., Zadar 2009., str. 51-78.

\section{MIĆANOVIĆ 2006}

Krešimir Mićanović, Hrvatski s naglaskom. Disput, Zagreb 2006.

\section{MIHALJEVIĆ ET AL. 2005}

Milica Mihaljević, Lana Hudečak, Anđela Frančić, Normativnost i višefunkcionalnost $u$ hrvatskome standardnome jeziku, Hrvatska sveučilišna naklada, Zagreb 2005.

\section{PRANJKOVIĆ 1998}

Ivo Pranjković, Izražavanje neodređenosti/ određenosti u hrvatskome jeziku, e-dokument: http://www-gewi.uni-graz.at/gralis/gralisarium/1998/Ivo_Pranjkovic_1998.html; 2. travnja 2013.

\section{PRANJKOVIĆ 2010}

Ivo Pranjković, Ogledi o jezičnoj pravilnosti, Disput, Zagreb 2010.

\section{SILIĆ 2006}

Josip Silić, Funkcionalni stilovi hrvatskoga jezika, Disput, Zagreb 2006.

\section{SILIĆ - PRANJKOVIĆ 2005}

Josip Silić, Ivo Pranjković, Gramatika hrvatskoga jezika za gimnazije i visoka učilišta, Školska knjiga, Zagreb 2005.

\section{ŠKILJAN 1988}

Dubravko Škiljan, Jezična politika. Naprijed, Zagreb 1988.

\section{ŠONJE 2000}

Jure Šonje (ur.), Rječnik hrvatskoga jezika, Leksikografski zavod Miroslava Krleže i ŠK, Zagreb 2000.

\section{ZNIKA 2006}

Marija Znika, "Kategorija određenosti kao predikatno ime", Jezik, 53/1,2006., str. 16-25.

\section{VUKUŠIĆ 1974}

Stjepan Vukušić, "Naglasci uporabne norme na osnovi startnog jezika", Jezik, XXI/3-4, 1974., 114-120.

\section{VUKUŠIĆ ET AL. 2007}

Stjepan Vukušić, Ivan Zoričić, Marija GrasselliVukušić, Naglasak u hrvatskome književnom jeziku, Nakladni zavod Globus, Zagreb 2007.

\section{ZORIČIĆ 1990}

Ivan Zoričić, Naglasni odnosi i norma, Školske novine, Zagreb 1990.

\section{ZORIČIĆ 1998}

Ivan Zoričić, Naglasak pridjeva u hrvatskome književnom jeziku, Pedagoški fakultet u Puli, Pula 1998.

\section{ZORIČIĆ 1995}

Ivan Zoričić, "O naravi naglasnih kolebanja u hrvatskom jeziku", Prvi hrvatski slavistički kongres - Zbornik radova, II, Pula 1995., 191-195.

\section{ZORIČIĆ 2001}

Ivan Zoričić, "Stilske vrijednosti u hrvatskome standardnom naglašavanju", Drugi hrvatski slavistički kongres - Zbornik radova, I, Zagreb 2001., 683-689. 


\section{SAŽETAK}

Odmake od kodificirane naglasne norme hrvatskoga standardnog jezika u ovome smo radu prikazali na primjeru pridjeva. Nakon komparativne analize suvremenih priručnika (gramatika, rječnika i savjetnika) i nakon anketiranja tzv. modelskih govornika (u ovome radu 45 studenata i studentica kroatistike i 22 srednjoškolskih profesora i profesorica različitih startnih idioma) zaključili smo da se i u pridjeva odmaci tiču prije svega inventara i raspodjele naglasaka. Kodeks podupire silazni ton koji se javlja i na nepočetnim slogovima riječi (u pridjevnih složenica) te pomicanje naglasaka ulijevo. Često dokidanje tonske opreke kratkih slogova te međuslogovnih preinaka naglasaka u neodređenih pridjeva (što utječe i na tipološka razvrstavanja, prelazak riječi iz promjenljivoga u nepromjenljivi tip) nije (opravdano) našlo mjesta u suvremenim priručnicima jer je naglasak razlikovni element u kategoriji određenosti/neodređenosti (i onda kada se formalni, gramatikalizirani, sve više gubi). Kodeks ne popušta ni čestome i proširenome gubljenju zanaglasnih dužina u govornika jer su one razlikovni element i kad naglasak to nije. Funkcionalnostilsko raslojavanje jezične stvarnosti i ovdje će pripomoći u opisivanju proširenih dvostrukosti i višestrukosti.

\section{SUMMARY}

\section{Accentuation of Adjectives in Speech Practice}

The paper presents the deviations from the codified accentuation norms of standard Croatian in the case of adjectives. After a comparative analysis of contemporary normative books of the Croatian language (grammar, vocabulary and advisor) and interviewing the, so called, model speakers (the study included 45 male and female Croatian language students and 22 secondary school teachers of different starting idioms), we have come to a conclusion that even in the case of adjectives the deviations are primarily related to the inventory and the distribution of accents. The codified accentuation norm of the standard Croatian language supports the downward tone occurring even in non-initial syllables (in compound adjectives) and the shifting of accents to the left. Frequent abatement of the tonal opposition of short syllables and intersyllabic accent modifications in indefinite adjectives (which affects the typological classification, words passing from changeable to non-changeable type) is nowhere to be found in the contemporary normative books, because accent is a distinctive feature in the category of definiteness/indefiniteness (even when the formal, grammaticalized one is increasingly fading away). The codified norm does not ease up even with regard to a frequent and extensive loss of post-accentual lengths, because they are a distinctive feature even when the accent is not. Functional and stylistic delayering of the linguistic reality will assist in describing extended doublets.

Keywords: adjectives, accent, codified accentuation norm, speech practice 